\title{
THE INTERACTION EFFECT OF INDEPENDENT BOARDS ON CORPORATE GOVERNANCE-CORPORATE SOCIAL RESPONSIBILITY (CG-CSR) AND PERFORMANCE NEXUS
}

\author{
Sitara Karim*, Norlida Abdul Manab, and Rusmawati Ismail \\ School of Economics, Finance and Banking, College of Business, \\ Universiti Utara Malaysia, 06010 Sintok, Kedah, Malaysia \\ *Corresponding author: sitarakarim.malik@gmail.com
}

Published online: 30 June 2020

To cite this article: Karim, S., Abdul Manab, N., \& Ismail, R. (2020). The interaction effect of independent boards on corporate governance-corporate social responsibility (CGCSR) and performance nexus. Asian Academy of Management Journal, 25(1), 61-84. https://doi.org/10.21315/aamj2020.25.1.4

To link to this article: https://doi.org/10.21315/aamj2020.25.1.4

\begin{abstract}
The financial crises over the past two decades were identified as the main reason for the economic collapse. Malaysia suffered the same fate when many organisations crumpled from inappropriate compliance of governance mechanisms and corporate social responsibility (CSR) disclosure practices. Given this condition, this study intends to examine the effects of governance mechanisms and CSR practice on firm performance and the moderating effect of board independence is investigated on corporate governance-CSR (CG-CSR) and performance nexus of 588 Malaysian companies listed on Bursa Malaysia between 2006 and 2017. Both accounting-based (ROA) and market-based (Tobin's Q) performance measures have been used for measuring performance. Dynamic model using Generalized Method of Moments (GMM) has been employed on the dataset to control for potential endogeneity, reverse causality, and dynamic heterogeneity. Findings indicate that ownership concentration negatively affects ROA; chief executive officer (CEO) duality positively affects ROA and negatively affects Tobin's Q. Moreover, investment on CSR is negatively related to both performance measures. Finally, board independence negatively moderates the CG mechanisms, CSR practice, and performance relationship. Findings of the study have implications for Bursa Malaysia and Securities Commission Malaysia to reset the limit of independent directors on board so that their unnecessary interference in operations of management may be avoided. Furthermore, companies need to reassess
\end{abstract}

(C) Asian Academy of Management and Penerbit Universiti Sains Malaysia, 2020. This work is licensed under the terms of the Creative Commons Attribution (CC BY) (http://creativecommons. org/licenses/by/4.0/). 
their CSR strategies whether they are spending on CSR activities or hiding their financial malfeasance in the name of investment on CSR.

Keywords: board independence, corporate governance, corporate social responsibility, firm performance, Malaysia

\section{INTRODUCTION}

While the interest in corporate governance (CG) and corporate social responsibility (CSR) is increasing, recent research has provided unclear and mixed results about their relationships. These relationships are examined in accordance with the agency theory and the stakeholder's theory in which each theory interprets the relationship between CG and CSR differently. According to Freeman's (1984) stakeholder's theory, and in addition to effective CG mechanisms, CSR must be used as an extension to resolve conflicts between managers and non-investing stakeholders. On the other hand, supporters of the agency theory argue that CSR is costly to the firm and managers tend to hide their failure or unfavourable performance by overinvesting in CSR activities thus breaching the CG's overinvestment prevention. Such practices do not maximise the firm's value, thus CSR is viewed as a waste of resources with a negative impact on CG (Barnea \& Rubin, 2010).

However, CG and CSR might be considered complementary to each other. Firms prove to survive without CSR engagement but suffer with the absence of CG practices. Jensen (2002) believes that CSR and CG are both indicators of the firm's fiduciary and moral commitments towards stakeholders, and he proposed the "enlightened stakeholder theory" by including the social responsibility aspects in the shareholder wealth maximisation. Based on an extensive literature review, Jamali et al. (2008) suggest that there is considerable overlap between CG and CSR. This overlap may be in the CG-CSR one way relationship part, since strong CG practices would result in CSR engagement. Accordingly, it is important to mention that CSR is not solely related to the social behaviour of the firm, but also to the marketplace, environment, and workplace (Karim et al., 2019a). Given this stance, another important element is the issue of skills gap and inadequate knowledge management strategies adopted by the board of directors (Hermalin \& Weisbach, 2003). Since Malaysia has been continuously striving to ensure effective governance practices while highlighting the role of efficient board of directors in the company but still there are discrepancies in compliance of CG codes by the listed firms in Malaysia that necessitate this study.

Additionally, Bursa Malaysia in its Corporate Governance Code (2017) has set the limit of more than a $50 \%$ representation of independent directors on board. 
In this way, many enhancements are needed in CG structures where board of directors may better monitor the firm. Moreover, weak compliance of CG codes, elevated agency issues between managers and shareholders, financial malfeasance, and inappropriate disclosure practices of Malaysian listed firms bring the issue to the limelight. Hence, this study is unique in investigating the interaction effect of independent board of directors on CG-CSR and performance relationship.

Based on the above arguments, there are two objectives of this study:

1. To examine the combined impact of CG mechanisms and CSR practice on firm performance in Malaysian listed companies

2. To investigate the moderating effects of board independence on CG-CSR and performance nexus

CG mechanisms examined in the study are ownership concentration, managerial ownership, institutional ownership, and chief executive officer (CEO) duality; whereas CSR practice investigated in this research is investment on CSR. In this way, the chief results of the study indicate ownership concentration to be negatively related to return on assets (ROA), CEO duality is positively linked to ROA whereas negatively associated with Tobin's Q. Moreover, investment on CSR is negatively related to both performance measures. As far as board independence is concerned, the presence of independent directors on the board negatively moderates the CG-CSR and performance relationship. The findings have novel implications for policy makers and regulatory authorities of Malaysia to assess the combined effect of CG mechanisms and CSR practice on performance of listed firms and to reduce the representation of the independent board of directors on the board to have their positive interaction effect on the given relationship. Moreover, for academia, this research is significant for uncovering new aspects of sustainable governance practices through different empirical and econometric approaches using the dynamic Generalized Method of Moments (GMM) for analysis.

\section{THEORETICAL FRAMEWORK}

Theories that contribute to the current study are agency theory and legitimacy theory. It is argued that the agency theory alone may not sufficiently inform CGCSR and performance nexus in diverse contexts and from diverse perspectives. A multi-theoretic approach to CG research is essential for recognising the many mechanisms and structures that might reasonably enhance organisational functioning. In this way, agency theory points to a potential conflict that may exist between the agent and the principal in an agency relationship. The policy 
prescription resulting from this theory is usually a mechanism to align the interests of the agent, who is likely to act in her own best interest and the principal (Jensen $\&$ Meckling, 1976). According to this theory, there are two ways of aligning the interests of agents and those of the principals, i.e., the first is monitoring the agent's behaviour to prevent him/her from engaging in opportunistic behaviour; and, the second is the provision of incentives and rewards for the agent to entice him/her into a behaviour that is aligned with the interest of the principal.

According to Liu and Taylor (2008) and Meyer and Rowan (1977), firms achieve corporate legitimacy when they adopt "proper organisational structures that comply with social norms and values." Thus, according to this theory, firms have to manage their organisational structures to earn corporate legitimacy. If they fail to adapt "appropriate" organisational structures, stakeholders and resource providers may threaten to withdraw the resources needed for the firm to carry out its normal activities (Wilmshurst \& Frost, 2000). In recent years, there has been an increasing focus on the structure and strategies adopted for ensuring effective CG mechanisms and CSR practices whereby the moderating effect of independent board of directors is examined as an added advantage for firms to maintain corporate legitimacy. Based on corporate legitimacy, it is posited that CG-CSR and firm performance relationship is likely to enhance corporate accountability, by providing a mechanism for independent oversight by independent boards of corporate activities, thus promoting corporate legitimacy.

Apart from these theories, Harjoto and Jo (2011) used four most noteworthy and representative hypotheses to elaborate the CG-CSR and performance nexus. Four hypotheses chosen for the study are over-investment hypothesis (Barnea \& Rubin, 2010; Jensen \& Meckling, 1976), strategic-choice hypothesis (Cespa \& Cestone, 2007), product-signaling/differentiation hypothesis (Fisman et al., 2006), and conflict resolution hypothesis (Scherer et al., 2006; Calton \& Payne, 2003; Jensen, 2002). Over-investment hypothesis (Barnea \& Rubin, 2010) contends that firms tend to over-invest in CSR activities to hide their financial misconducts whereas strategic choice hypothesis argues that incumbent CEOs strategically choose CSR activities to generate support from social and environmental activities to reduce the probability of CEO turnover (Cespa \& Cestone, 2007). Correspondingly, firms use CSR activities to signal their product quality, especially those that operate in highly competitive market (product-signaling/differentiation hypothesis). Finally, Calton and Payne (2003) and Scherer et al. (2006) believe that firms use CSR activities to reduce conflict of interest between managers, investing and noninvesting stakeholders (conflict-resolution hypothesis). For current study, support of various hypotheses has been taken for empirical justification. 


\section{LITERATURE REVIEW AND HYPOTHESES DEVELOPMENT}

In the subsequent discussion, literature review of earlier empirical studies concerning CG mechanisms such as ownership concentration, managerial ownership, institutional ownership and CEO duality, and CSR practice, i.e., investment on CSR and its impact on firm performance is presented. Moreover, the interaction effect of board independence is also reviewed based on prior literature.

\section{Ownership Concentration and Firm Performance}

Ownership concentration determines whether the ownership is scattered or limited to three to five owners. This may be referred to as block holder ownership where ownership is confined to three to five owners. Agency theory contends that agency conflicts occur between principals and agents because of widely dispersed ownership and the separation of shareholders and management (Jensen \& Meckling, 1976). La Porta et al. (2000) described this concept as prospective cause of conflict of interest between major and minor shareholders. However, block holder ownership is considered as a way to decrease the conflict of interest between shareholders and management. Furthermore, agency theory is based on the rationale that there is a separation between management and ownership and due to this separation, problems of interest arise between the owners and managers as the opportunistic behaviour of the managers would jeopardise the owners' interests (Lam \& Lee, 2012). However, agency conflicts also occur between majority and minority shareholders as a result of concentrated shareholdings in the hands of few shareholders on account of other shareholders (AlQadasi \& Abidin, 2018).

Based on agency theory claims, it is hypothesised that:

$\mathrm{H}_{1}$ : Ownership concentration is negatively related to firm performance

\section{Managerial Ownership and Firm Performance}

Managerial ownership defines the stake and proportion of shares held by the managers of firm (Mishra \& Kapil, 2017). A common notion prevails that managers will work for the best interests of organisations when they have ownership in the firm (Alabdullah, 2018). Or else, a potential conflict of interest between managers and owners of the firm can be raised. The arguments of Shleifer and Vishny (1997) are noteworthy for explaining this phenomenon from incentive perspective and entrenchment perspective (Mitra et al., 2017). Incentive perspective, they claim, explains that managers take up different investment strategies that tend to reduce 
the payment to outside suppliers of funds and it can only be possible when there is high level of managerial ownership within the firm (Alabdullah, 2018).

Contrarily, entrenchment perspective contends high managerial ownership brings fewer chances for outsiders to interfere in the management affairs. Taking both perspectives simultaneously, the relationship between managerial ownership and firm performance seems non-linear (Shan, 2017). The agency issues between shareholders and management may encourage the managers to exert less effort to administrate the firm (Shan, 2017). Moreover, these issues may lead the managers to use available resources for their personal well-being. However, agency problem may be reduced if managers hold large fraction of the firm's equity (Alabdullah, 2018). Thus, an increase in proportion of shares owned by the managers may help to align the interest of managers and shareholders by restricting them not to waste the firm's resources for their own well-being (Ofoeda, 2017; Mishra \& Kapil, 2017). Based on entrenchment perspective, it is hypothesised that:

$\mathrm{H}_{2}$ : Managerial ownership is negatively linked to firm performance

\section{Institutional Ownership and Firm Performance}

Institutional investors have a very significant role in CG and they are concerned with reducing agency costs in the firms as they have both the motivation and intention to monitor the managers to safeguard their interest (Panda \& Leepsa, 2019; Mehdi et al., 2017). Moreover, they can directly participate in firm's decision-making process by pressuring the board of directors and disciplining the management (Wang, 2016). Based on the monitoring role of institutional investors, Pound (1988) presented three hypotheses namely efficient monitoring, conflict of interest, and strategic alliance to explicate the relationship between firm value and institutional shareholdings where efficient monitoring hypothesis predicts that institutional investors can monitor the management more effectively than small investors.

Contrarily, conflict of interest hypothesis suggest that institutional investors are forced to use their right to vote in favour of management on account of their other business relationships (Aluchna \& Kaminski, 2017). However, strategic alignment hypothesis predict that managers and institutional investors may find it valuable to cooperate in the best interests of organisations (Young \& Wu, 2017). Yet, this cooperation diminishes the favourable effects on corporate value that could result from intense monitoring of institutional shareholders (Al-Saidi \& Al-Shammari, 2015; Arouri et al., 2014). Based on Pound's (1988) conflict of interest assumption, it is hypothesised that: 
$\mathrm{H}_{3}$ : Institutional ownership is negatively associated with firm performance

\section{CEO Duality and Firm Performance}

The advocates of organisational theories suggest that duality enhances unity of command (Garas \& ElMassah, 2018). However, the proponents of agency theory (Nas \& Kalaycioglu, 2016; Duru et al., 2016) suggest that avoiding duality limits potential CEO entrenchment. Contrarily, Finkelstein and D'Aveni (1994) explained role duality through agency and stewardship theory arguing that agency problems arise when the same person holds two positions on the board, leading towards performance inefficiency and ultimately towards conflict of interest (Sheikh \& Karim, 2015). However, CEO duality is synonymous with poor performance and weaker monitoring, establishes dependence, decreases board monitoring effectiveness, and increases CEO entrenchment (Nuanpradit, 2019).

Despite these arguments, Lipton and Lorsch (1992) defended the agency theory in the context of improved efficiency, enhanced performance, and effective management mentoring if two positions work separately (Hassan \& Habouni, 2013). While stewardship theory (Davis et al., 1997) supports this concept and explains that performance and efficiency enhance over time when same person holds two positions because it depicts clear picture of roles and responsibilities to the person holding two positions on the board (Sheikh \& Karim, 2015). Therefore, based on agency theory, it is hypothesised that:

$\mathrm{H}_{4}$ : CEO duality is negatively linked to firm performance

\section{Investment on CSR and Firm Performance}

Porter and Kramer (2006) stated that CSR can be a source of opportunity, innovation, and competitive advantage when used appropriately. Particularly, firms can simultaneously enhance their competitiveness in the markets and advance the economic and social conditions in the communities when adopting policies and practices aiming at creating "shared value." Alternatively, firms face trade-off between social responsibility and firm performance, placing them in a disadvantageous cost position incurring agency costs where managers attain private benefits from building the reputation as good social citizen at the expense of shareholders (Kotchen \& Moon, 2012; Harjoto \& Jo, 2011; Barnea \& Rubin, 2010).

Additionally, corporate legitimacy argues that firms tend to engage in CSR activities to build their own personal reputation as good global tycoons (over-investment 
hypothesis). And, it is their legitimate responsibility (Karim et al., 2019) to comply with the regulations of top authorities of their respective nations (Al-Malkawi \& Javaid, 2018). In this way, investment on CSR provides ground for firms to assess their CSR strategies and identify the discrepancies where corporate resources are being misused by the managers (Karim et al., 2019a) for their private benefits. Based on these arguments, it is hypothesised that:

$\mathrm{H}_{5}$ : Investment on CSR negatively affects firm performance

\section{Interaction Effect of Board Independence}

The company board is constituted to reduce the cost associated with conflict between owners and management (Ashfaq \& Rui, 2018) and taking into account the concerns relating to stakeholders. The shareholders main interest is to maximise firm value while the interest of the management is to maximise their benefits (Olson et al., 2018). In this situation, CG mechanisms are usually introduced to deal with this condition and minimise the conflict. Thus, a number of CG mechanisms have been proposed to ensure the effectiveness of monitoring in solving agency problems between management and owners and gaining stakeholders' interests. Though the board delegates both management functions and decision control functions to internal managers, they retain final control over the managers through the right to ratify key operational decisions (Duru et al., 2016). As Coles et al. (2008) contend, complex firms should have higher board independence for better advice to the firm's CEO (Karim et al., 2019b; Sheikh \& Karim, 2015).

The role of the board of directors as an effective monitoring mechanism for management is dependent upon them being non-executive and independent. Furthermore, the inclusion of independent directors on corporate boards is an effective mechanism to reduce the potential divergence between management and shareholders. Several empirical researches include board independence to explore the moderating impact on the respective relationships with mixed results $(\mathrm{Wu} \&$ $\mathrm{Wu}, 2014$; Duru et al., 2016). These studies argue that interest of independent directors is linked with lower-risk investment decisions. Contrarily, it is also claimed that excessive involvement of independent directors in the daily affairs of organisations may restrict the managers to perform their functions liberally. Thus, it is hypothesised that:

$\mathrm{H}_{6}$ : Board independence negatively moderates the relationship between CG mechanisms, CSR practice and firm performance 


\section{RESEARCH METHOD}

\section{Data and Variables}

This study used the data of Malaysian non-financial companies listed on Bursa Malaysia for the period 2006-2017. The data were mainly extracted from annual reports of firms; however, datastream is used for obtaining data relevant to performance variables such as ROA and Tobin's Q. Unbalance panel data is employed for the study due to unavailability of annual reports of few listed companies. Data of financial companies have been excluded from the dataset due to the different nature of business of these firms. Therefore, final sample consists of 5501 firm-year observations of 588 listed firms in Malaysia during 2006-2017. The reason for choosing Malaysian listed firms is that Malaysia is an emerging economy which suffered several economic twists and turns since its birth. Despite these ups and downs, the country has successfully maintained its reputation in the corporate world. Additionally, the time period of 2006-2017 is chosen because more than 10 years of panel data are considered sufficient for econometric analysis and estimation process.

This study aims to investigate the influence of CG and CSR on firm performance where $\mathrm{CG}$ attributes chosen for the study are ownership concentration, managerial ownership, institutional ownership, and CEO duality whereas the CSR measure adopted in the study is investment on CSR. Ehsan and Kaleem (2012) used the measure of CSR as investment on CSR where investment on CSR denotes "Donations + Workers' Welfare Fund/Earnings before Tax." However, this study uses donations, sponsorships, scholarships, and investment on welfare programs is set as a measure of investment on CSR in Malaysian context. Moreover, this study also examines the moderating role of board independence on the relationship between CG mechanisms, CSR practice, and firm performance. However, two control variables, i.e., firm size and leverage are employed to control for firmspecific characteristics. Table 1 presents the operational definition and measurement of variables utilised in the study. 
Table 1

Operational definition and measurement of variables

\begin{tabular}{|c|c|c|}
\hline Variables & Proxy & Definition \\
\hline \multicolumn{3}{|l|}{ Dependent variables } \\
\hline Return on assets & $R O A_{i t}$ & Net income to total assets. \\
\hline Tobin's Q & $T Q_{i t}$ & $\begin{array}{l}\text { Market value of equity added to the book value of } \\
\text { the debt over the book value of the total assets. }\end{array}$ \\
\hline \multicolumn{3}{|l|}{ Independent variables } \\
\hline Ownership concentration & $O W N C_{i t}$ & $\begin{array}{l}\text { Shares held by } 5-10 \text { largest shareholders to } \\
\text { outstanding common shares. }\end{array}$ \\
\hline Managerial ownership & $M O W N_{i t}$ & $\begin{array}{l}\text { Shares held by managers to total outstanding } \\
\text { common shares. }\end{array}$ \\
\hline Institutional ownership & $I O W N_{i t}$ & $\begin{array}{l}\text { Shares held by institutions to total outstanding } \\
\text { common shares. }\end{array}$ \\
\hline CEO duality & $C E O D_{i t}$ & $\begin{array}{l}\text { A dummy variable, } 1 \text { if CEO is the chairman of the } \\
\text { board and } 0 \text { otherwise. }\end{array}$ \\
\hline Investment on CSR & $I C S R_{i t}$ & $\begin{array}{l}\text { A dummy variable, } 1 \text { if investment on CSR } \\
\text { available and } 0 \text { otherwise. }\end{array}$ \\
\hline \multicolumn{3}{|l|}{ Moderating variable } \\
\hline Board independence & $B I N D_{i t}$ & $\begin{array}{l}\text { Proportion of independent directors to total number } \\
\text { of board directors. }\end{array}$ \\
\hline \multicolumn{3}{|l|}{ Control variables } \\
\hline Firm size & $S I Z E_{i t}$ & Natural logarithm of total assets. \\
\hline Leverage & $L E V_{i t}$ & Total liabilities to total assets. \\
\hline
\end{tabular}

\section{Research Framework}

Figure 1 presents the research framework of the study for better illustration of variables and their relationship. 
Independent Variables

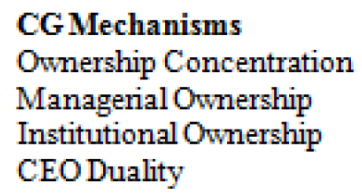

\section{Control Variables}

Firm Size

Leverage
Dependent Variables

Firm Performance

Retum on Assets

Tobin's Q

Figure 1. Research framework

\section{METHODOLOGY}

This study employs a dynamic system of GMM for estimations and analyses of data. Since static estimations are considered incompetent for explaining coherent results of variables, the dynamic model using system GMM produces reliable and accurate results (Arellano \& Bover, 1995; Arellano \& Bond, 1991). The main problem is that quite frequently a firm's variables are endogenously related with dependent variables (Arellano \& Bover, 1995). Cross-sectional data do not allow for correction of unobservable heterogeneity. When unobserved firm characteristics are correlated with exogenous variables, estimated coefficients will be biased (Bond, 2002). An initial solution to the endogeneity problem is to use panel data. Estimating fixed-effect models or models in differences is an efficient solution. However, it is only workable when the unobservable characteristics are time-variant. For CG-CSR, it is quite complicated to know which firm-specific courses of action enhance firm performance. In the current study, the sample may contain firm's unobserved characteristics that could be time varying and fixedeffect model is insufficient to eliminate spurious relationships between CG-CSR and firm performance. Subsequently, more model structure is required to improve understanding of how CG-CSR impact firm performance. As a solution, the study followed Arellano and Bond (1991) and Arellano and Bover (1995) using dynamic 
panel data model approach with lagged endogenous variables as instruments, provided they met the conditions for valid instruments.

Dynamic models are specified with lagged dependent variables and control for unobserved heterogeneity, reverse causality, simultaneity, and dynamic endogeneity. Furthermore, dynamic models basically concentrate on single equation and autoregressive distributive lag models where large number of crosssection units and small number of time periods bring consistent outcomes (Bond, 2002). Therefore, regression models for this study are as follows:

$$
\begin{aligned}
& R O A_{i t}=\beta_{0}+\beta_{1} O W N C_{i t}+\beta_{2} M O W N_{i t}+\beta_{3} I O W N_{i t}+\beta_{4} C E O D_{i t}+ \\
& \beta_{5} I C S R_{i t}+\beta_{6} S I Z E_{i t}+\beta_{7} L E V_{i t}+\beta_{8} R O A_{i t-1}+\varepsilon_{i t} \\
& T Q_{i t}=\beta_{0}+\beta_{1} O W N C_{i t}+\beta_{2} M O W N_{i t}+\beta_{3} I O W N_{i t}+\beta_{4} C E O D_{i t}+ \\
& \beta_{5} I C S R_{i t}+\beta_{6} S I Z E_{i t}+\beta_{7} L E V_{i t}+\beta_{8} T Q_{i t-1}+\varepsilon_{i t}
\end{aligned}
$$

However, for investigating the moderating role of board independence on the relationship between CG mechanisms, CSR practice and firm performance, the regression equations are as follows:

$$
\begin{aligned}
& R O A_{i t}=\beta_{0}+\beta_{1} O W N C_{i t} * B I N D_{i t}+\beta_{2} M O W N_{i t} * B I N D_{i t}+ \\
& \beta_{3} I O W N_{i t} * B I N D_{i t}+\beta_{4} C E O D_{i t} * B I N D_{i t}+ \\
& \beta_{5} I C S R_{i t} * B I N D_{i t}+\varepsilon_{i t} \\
& T Q_{i t}=\beta_{0}+\beta_{1} O W N C_{i t} * B I N D_{i t}+\beta_{2} M O W N_{i t} * B I N D_{i t}+ \\
& \beta_{3} I O W N_{i t} * B I N D_{i t}+\beta_{4} C E O D_{i t} * B I N D_{i t}+ \\
& \beta_{5} I C S R_{i t} * B I N D_{i t}+\varepsilon_{i t}
\end{aligned}
$$

In the equations, $R O A_{i t}$ is return on assets and $T Q_{i t}$ is Tobin's $\mathrm{Q}$ for $i$ th company at time $t . O W N C_{i t}, M O W N_{i t}$ and $I O W N_{i t}$ are ownership concentration, managerial ownership, and institutional ownership for $i$ th company at time $t$, respectively. Moreover, $C E O D_{i t}$ and $I C S R_{i t}$ are CEO duality and investment on CSR for $i$ th company at time $t$, respectively. $S I Z E_{i t}$ and $L E V_{i t}$ denote control variables namely firm size and leverage for $i$ th company at time $t$, respectively. Equations 3 and 4 exhibit the interaction terms for CG mechanisms, CSR practice, and performance relationship and board independence. $R O A_{i t-1}$ and $T Q_{i t-1}$ are one year lagged values of return on assets and Tobin's Q. Additionally, $\beta_{0}$ is the intercept, $\varepsilon_{i t}$ is the random error term for $i$ th company at time $t . \beta_{1}-\beta_{7}$ are the coefficients of concerned explanatory and control variables. 


\section{EMPIRICAL RESULTS}

\section{Descriptive Statistics and Correlation Matrix}

Table 2 presents descriptive statistics of the variables of the study where mean value of return on assets $\left(R O A_{i t}\right)$ is 0.004 indicating that, on average, firms are losing 0.004 cents profit for RM1 of total assets. The mean value of Tobin's Q is 1.26 which indicates the proportion of market value to the book value of company's total assets. Ownership concentration shows the mean value of $51.14 \%$, suggesting that ownership of Malaysian listed companies is $51.14 \%$ concentrated. Moreover, $12.78 \%$ shares are held by managers and their spouses, whereas institutional ownership is $34.56 \%$ in Malaysia. CEO duality depicts the mean value of $8.01 \%$ indicating that only $8.01 \%$ firms have their CEOs as chairmen of the company. Moreover, investment on CSR shows the average value of $71.27 \%$ indicating that more than $70 \%$ of Malaysian firms invest on CSR activities. Additionally, firm size indicates the mean value of 12.96 and leverage shows $41.67 \%$ presenting the financing pattern of Malaysian Listed Companies.

Table 2

Descriptive statistics

\begin{tabular}{lccccc}
\hline Variable & Obs. & Mean & Std. dev. & Min & Max \\
\hline$R O A_{i t}$ & 5501 & -0.0040 & 1.5541 & -48.226 & 10.756 \\
$T Q_{i t}$ & 5501 & 1.2610 & 2.3051 & -6.95 & 34.38 \\
$O W N C_{i t}$ & 5501 & 0.5114 & 0.3283 & 0.0520 & 5.0766 \\
$\operatorname{MOWN}_{i t}$ & 5501 & 0.1278 & 0.1732 & 0 & 0.7400 \\
$I O W N_{i t}$ & 5501 & 0.3456 & 0.1805 & 0.0077 & 1.7145 \\
CEOD $_{i t}$ & 5501 & 0.0801 & 0.2715 & 0 & 1 \\
$I C S R_{i t}$ & 5501 & 0.7127 & 0.4525 & 0 & 1 \\
$\operatorname{SIZE}_{i t}$ & 5501 & 12.964 & 1.5580 & 7.6797 & 18.521 \\
$\operatorname{LEV}_{i t}$ & 5501 & 0.4167 & 0.4067 & 0.0010 & 10.319 \\
\hline
\end{tabular}

Correspondingly, Table 3 depicts the correlation matrix of dependent and independent variables where the figures illustrate fairly small values pointing no element of multicollinearity among the variables. 


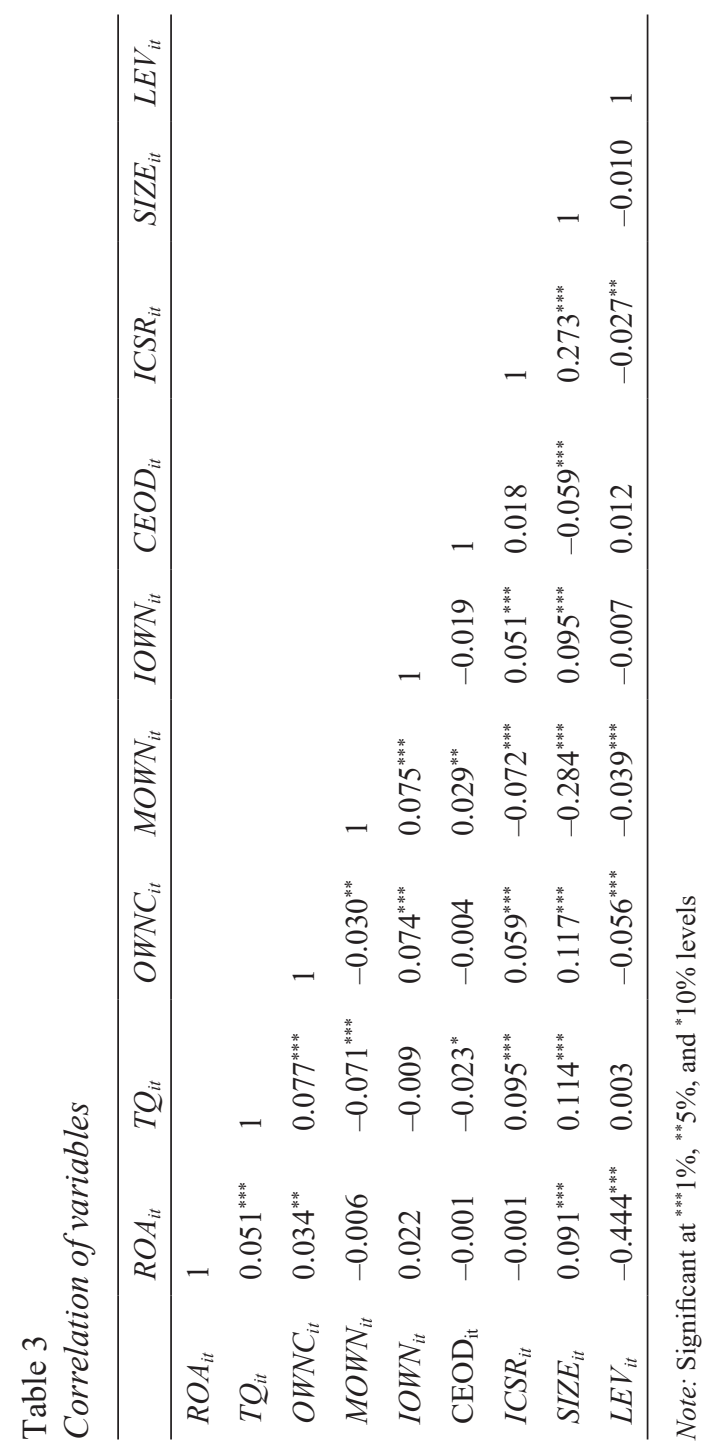




\section{Multicollinearity Test using Variance Inflation Factor}

Variance inflation factor (VIF) test was carried out to determine whether there exists high collinearity between the independent variables or not. In other words, whether two or more variables are measuring the same thing or variables are independent of one another. Hair et al. (2010) suggested that VIF of less than 10 would indicate no serious multicollinearity problem amongst the paired variables. Hair et al. (2010) stated that one of the various methods to check for the existence of the correlation among independent variables is through multicollinearity test that explains the level by which one variable's effect could be managed by the other variable. However, variance inflation factor is the technique to check for multicollinearity. For the dataset of current study, no problem of multicollinearity existed after running regressions on the dataset as depicted in Table 4.

Table 4

Multicollinearity test using VIF

\begin{tabular}{lcccc}
\hline Variables & VIF $\left(R O A_{i t}\right)$ & $1 / \mathrm{VIF}\left(R O A_{i t}\right)$ & $\mathrm{VIF}\left(T Q_{i t}\right)$ & $1 / \mathrm{VIF}\left(T Q_{i t}\right)$ \\
\hline$O W N C_{i t}$ & 1.03 & 0.270 & 1.25 & 0.302 \\
$M O W N_{i t}$ & 2.01 & 0.498 & 2.63 & 0.265 \\
$I O W N_{i t}$ & 1.98 & 0.505 & 1.98 & 0.526 \\
$C_{E O D_{i t}}$ & 3.06 & 0.268 & 2.01 & 0.542 \\
$I C S R_{i t}$ & 2.78 & 0.322 & 3.06 & 0.230 \\
IIZE $_{i t}$ & 2.34 & 0.359 & 2.34 & 0.425 \\
LEV $_{i t}$ & 1.15 & 0.427 & 1.21 & 0.412 \\
Mean VIF & 2.05 & 0.372 & 2.06 & 0.384 \\
\hline
\end{tabular}

\section{Heteroskedasticity Test}

The following hypothesis was tested to ascertain the variance consistency of the random error through Breusch-Pagan/Cook-Weisberg test for heteroskedasticity where alternate hypothesis predicts constant variance of regression model. After running the regressions, the results of the heteroskedasticity tests indicate that the probability values of chi-square for each regression are far greater than $5 \%$ rejection region as shown in Table 5 . 
Table 5

Heteroskedasticity test

\begin{tabular}{lcc}
\hline & $R O A_{i t}$ & $T Q_{i t}$ \\
\hline Chi2 (1) & 0.02 & 0.04 \\
Prob $>$ Chi2 & 0.8759 & 0.7452 \\
\hline
\end{tabular}

\section{System GMM Regression Results}

As stated earlier, this study employs dynamic modeling for estimation process of the dataset as system GMM gives accurate and precise results. Table 6 exhibits the regression results of the impact of CG mechanisms and CSR practice on return on assets. However, in system GMM, one year lagged value of return on assets is used. The findings reveal that ownership concentration and managerial ownership are negatively linked with $R O A_{i t-l}$ but the relationship is significant with ownership concentration. Institutional ownership and CEO duality are positively related with $R O A_{i t-l}$ but significant relationship is observed between CEO duality and $R O A_{i t-l}$. Furthermore, investment on CSR negatively and significantly affects $R O A_{i t-l}$. For control variables, firm size is positively significant and leverage is negatively significant with $R O A_{i t-1}$. Consequently, this study used Sargan test for overidentification problem and Arellano-Bond test for the problem of autocorrelation. The values of both tests are greater than 0.05 (95\% significance level) leaving no cause for over-identification and autocorrelation problem.

Table 7 gives the results relating the impact of CG attributes and CSR practice on Tobin's Q. Findings indicate ownership concentration and institutional ownership are positively related, whereas managerial ownership and CEO duality are negatively related to market based performance measure. However, the relationship is only significant with CEO duality. Furthermore, the investment on CSR is also negative and significantly associated with $T Q_{i t-1}$. Concerning control variables, firm size is positively insignificant whereas leverage is negatively significant with $T Q_{i t-1}$. Besides, the values of Sargan test and Arellano-Bond test indicate reasonably greater values than 0.05 showing no problem of over-identification and autocorrelation.

Additionally, this study also examines the moderating role of board independence on CG mechanisms, CSR practice, and performance relationship. Table 8 depicts regression results of the moderating role of board independence of the given relationship. As indicated in the table, the majority of the variables showed significant negative relationships with board independence as moderator. Thus, it is 
suggested that board independence negatively moderates the relationship between CG attributes, CSR practice and firm performance in Malaysian listed companies.

In sum, ownership concentration is negatively related to return on assets; CEO duality positively affects $R O A_{i t-1}$ whereas negatively affects $T Q_{i t-1}$. Moreover, investment on CSR is negatively linked to both performance measures. Firm size is positively associated with return on assets and leverage is negatively linked with both performance measures. Additionally, board independence negatively moderates the relationship between CG attributes, CSR practice and firm performance.

Table 6

Effects of explanatory variables on return on assets $\left(R O A_{i t-1}\right)$ using $G M M$

\begin{tabular}{lllll}
\hline Variable & Coefficients & Std. err. & $z$-statistic & Probability \\
\hline$C$ & -0.8157 & 0.5015 & -1.63 & 0.104 \\
$O W N C_{i t}$ & -0.7460 & 0.3583 & -2.08 & 0.037 \\
MOWN $_{i t}$ & -0.5914 & 0.4307 & -1.37 & 0.170 \\
IOWN $_{i t}$ & 0.1763 & 0.4251 & 0.41 & 0.678 \\
CEOD $_{i t}$ & 0.6689 & 0.2333 & 2.87 & 0.004 \\
ICSR $_{i t}$ & -0.0402 & 0.0185 & -2.17 & 0.030 \\
SIZE $_{i t}$ & 0.1502 & 0.0264 & 5.68 & 0.000 \\
LEV $_{i t}$ & -1.9202 & 0.0929 & -20.65 & 0.000 \\
L1 $_{\text {Sargan test for over-identifying restriction: } p \text { value }}$ & & -3.26 & 0.001 \\
Arellano-Bond test for 1st order & & & 0.0872 \\
\hline
\end{tabular}


Sitara Karim et al.

Table 7

Effects of explanatory variables on Tobin's $Q$ (TQ $\left.Q_{i t-1}\right)$ using $G M M$

\begin{tabular}{lllll}
\hline Variable & Coefficients & Std. err. & $z$-statistic & Probability \\
\hline$C$ & -0.4421 & 1.0275 & -0.43 & 0.667 \\
$O W N C_{i t}$ & 0.3918 & 0.5019 & 0.78 & 0.435 \\
$M O W N_{i t}$ & -1.0308 & 0.7562 & -1.36 & 0.173 \\
$I O W N_{i t}$ & 0.4142 & 0.4672 & 0.89 & 0.375 \\
$C E O D_{i t}$ & -0.4377 & 0.2168 & -2.02 & 0.044 \\
$I C S R_{i t}$ & -0.0762 & 0.0387 & -1.97 & 0.049 \\
$S_{Z Z E_{i t}}$ & 0.0803 & 0.0759 & 1.06 & 0.290 \\
LEV $_{i t}$ & -0.0835 & 0.0371 & -2.25 & 0.024 \\
$L^{1}$ & 0.2891 & 0.0189 & 15.29 & 0.000 \\
Sargan test for over-identifying restriction: $p$ value & & 0.0952 \\
Arellano-Bond test for 1st order & & & 0.1079 \\
\hline
\end{tabular}

Table 8

Moderating effect of BIND ${ }_{i t}$ on CG mechanisms, CSR practice, and firm performance

\begin{tabular}{lll}
\hline Variable & $R O A_{i t}$ & $T Q_{i t}$ \\
\hline$C$ & $-1.3033^{* * *}$ & $-0.5103^{* *}$ \\
$O W N C_{i t} * B I N D_{i t}$ & $-1.5651^{* * *}$ & $-1.7413^{* * *}$ \\
$M O W N_{i t}^{*} B I N D_{i t}$ & -0.0991 & -0.0386 \\
$I O W N_{i t}^{*} B I N D_{i t}$ & $-1.6969^{* * *}$ & $-1.4534^{* * *}$ \\
$C E O D_{i t} * B I N D_{i t}$ & $-0.4956^{* * *}$ & $-0.0152^{* *}$ \\
$I C S R_{i t} * B I N D_{i t}$ & $-0.0282^{*}$ & $-0.3043^{* *}$ \\
$R^{2}$ & 0.1150 & 0.2735 \\
Adjusted $R^{2}$ & 0.1360 & 0.2547 \\
Root MSE & 1.5436 & 1.2758 \\
\hline
\end{tabular}

Note: Significant at ${ }^{* * *} 1 \%,{ }^{* *} 5 \%$ and ${ }^{*} 10 \%$ levels 


\section{DISCUSSION}

The aims of this study are to assess the impacts of CG mechanisms and CSR practice on firm performance and to examine the moderating role of board independence on the given relationship. The regression results indicate that ownership concentration is negatively affecting $R O A_{i t-l}$ whereas it does not affect $T Q_{i t-1}$. The negative relationship confirms the prediction of agency theory which contends that top managers, acting as agents of stockholders, can pursue courses of action that may not be parallel to the interests of the owners (Jensen \& Meckling, 1976). Moreover, it is the prospective cause of conflict of interest between major and minor shareholders that brings costs to the firm when block holders tend to maximise value for their own interests and divest minor owners on their part of the left over returns (La Porta et al., 2000). This finding is consistent with the findings of Sheikh and Karim (2015).

Correspondingly, CEO duality is positively related to lag value of return on assets and negatively associated with lagged Tobin's $Q$ value. This finding inculcates that CEO duality is beneficial for internal affairs of the company because it depicts a clear picture of roles and responsibilities to the person holding two positions, confirming the prophecy of Stewardship theory (Davis et al., 1997). Alternatively, CEO duality is negatively associated with market based performance measure, confirming the predictions of agency theory, contending CEO duality enhances agency problems that ultimately lead firms towards conflict of interest. Furthermore, role duality and its substantial negative impact on market return are responsible for minimising the market value of firms in Malaysia. However, the positive result is consistent with the studies of Sheikh and Karim (2015) and the negative relationship is consistent with Duru et al. (2016), and Hassan and Halbouni (2013).

Concerning the CSR practice, i.e., investment on CSR and its effect on firm performance indicates the negative relationship with both performance measures. The probable explanation for this relationship is that firms face trade-off between social responsibility and firm performance, placing them in a disadvantageous cost position incurring agency costs where managers attain private benefits from building the reputation as good social citizen at the expense of shareholders (Barnea $\&$ Rubin, 2010). Therefore, CSR have value-decreasing impact in the face of high level managerial entrenchment where managers overinvest in CSR activities for their personal benefits to camouflage their corporate misconduct (Kotchen \& Moon, 2012; Harjoto \& Jo, 2011). It indicates that managers of Malaysian firms overinvest in the CSR activities in order to hide their financial misconduct, thus creating agency costs for firms and negatively affecting firm performance. 
Furthermore, board independence negatively moderates the significant relationship between CG mechanisms, CSR practice, and firm performance. This outcome confirms the predictions of agency theory where higher outsider representation is the prospective cause of conflict of interest between shareholders and management. However, this result suggests that excessive involvement of the independent directors in the daily affairs of organisations may restrict the managers to perform their functions liberally, hence negatively moderating the relationship. However, this finding is analogous to the finding of $\mathrm{Wu}$ and $\mathrm{Wu}(2014)$.

Findings related to control variables suggest a positive relationship between firm size and $R O A_{i t-1}$ due to scale economies where organisations get resources at lower cost but at greater diversification. However, the finding is parallel to the results of Hassan and Halbouni (2013) and Ofoeda (2017). Alternatively, the negative relationship between leverage and firm performance suggests that agency issues are the potential cause of firms to use higher levels of debt, limiting managers to perform firm's operations effectively, thus negatively affecting the performance. Conversely, the negative relationship is in congruence with Mishra and Kapil (2017).

\section{CONCLUSION}

Conclusively, this study attempts to investigate the joint impacts of CG mechanisms and CSR practice on firm performance and to examine the moderating role of board independence of the given relationship. Findings of the study provide significant insights for regulatory bodies of Malaysia such as Securities Commission (SC) Malaysia and Bursa Malaysia. SC Malaysia is continuously striving for better CG mechanisms over the period of 18 years by providing continuous amendments in CG codes. It is prime responsibility of SC Malaysia to oversee the compliance of the code by listed firms in Malaysia. As far as findings related to ownership structure are concerned, SC Malaysia needs to incorporate the specifications of ownership structure in the code as such there is no amendment provided to the listed companies by the SC Malaysia. For policy makers, the study necessitates that they must shift their ownership patterns from concentrated to dispersed for ensuring effective $\mathrm{CG}$ in their firms.

Accordingly, it must be monitored regularly by the top management of the firms whether the corporate resources are being utilised for socially responsible projects or they are being misused by the managers for their private benefits and personal motives. Furthermore, the negative interaction effect of board independence 
inculcates that SC Malaysia must revisit the requirement of $50 \%$ independent boards for ensuring better monitoring role by the outsiders.

For academia, the study obtains support from agency theory and legitimacy theory for explaining the majority of the relationships. In addition, several hypotheses have also been discussed to explain the relationships between CG-CSR and performance. However, there are certain limitations of the study as well. For instance, the study considers the data of only one country. For ensuring generalisability of research, the same research can be applied to other emerging and developed economies. Moreover, the study included few CG mechanisms and CSR practice and for future research, other significant governance and CSR variables can be included.

\section{REFERENCES}

Alabdullah, T.T.Y. (2018). The relationship between ownership structure and firm performance: Evidence from Jordan. Benchmarking: An International Journal, 25(1), 319-333. https://doi.org/10.1108/BIJ-04-2016-0051

AlQadasi, A., \& Abidin, S. (2018). The effectiveness of internal corporate governance and audit quality: the role of ownership concentration - Malaysian evidence. Corporate Governance: The International Journal of Business in Society, 18(2), 233-253. https://doi.org/10.1108/CG-02-2017-0043

Al-Saidi, M., \& Al-Shammari, B. (2015). Ownership concentration, ownership composition and the performance of the Kuwaiti listed non-financial firms. International Journal of Commerce and Management, 25(1), 108-132. https://doi.org/10.1108/ IJCOMA-07-2013-0065

Aluchna, M., \& Kaminski, B. (2017). Ownership structure and company performance: A panel study from Poland. Baltic Journal of Management, 12(4), 485-502. https:// doi.org/10.1108/BJM-01-2017-0025

Arellano, M., \& Bond, S. (1991). Some tests of specification for panel data: Monte Carlo evidence and an application to employment equations. The Review of Economic Studies, 58(2), 277-297. https://doi.org/10.2307/2297968

Arellano, M., \& Bover, O. (1995). Another look at the instrumental variable estimation of error-components models. Journal of Econometrics, 95, 29-51. https://doi. org/10.1016/0304-4076(94)01642-D

Arouri, H., Hossain, M., \& Muttakin, M.B. (2014). Effects of board and ownership structure on corporate performance: Evidence from GCC countries. Journal of Accounting in Emerging Economies, 4(1), 117-130. https://doi.org/10.1108/JAEE-02-20120007

Ashfaq, K., \& Rui, Z. (2018). Revisiting the relationship between corporate governance and corporate social and environmental disclosure practices in Pakistan. Social Responsibility Journal, 15(1), 90-119. https://doi.org/10.1108/SRJ-01-2017 $-0001$ 
Barnea, A., \& Rubin, A. (2010). Corporate social responsibility as a conflict between shareholders. Journal of Business Ethics, 97, 71-86. https://doi.org/10.1007/ s10551-010-0496-z

Bond, S.R. (2002). Dynamic panel data models: A guide to micro data methods and practice. Portuguese Economic Journal, 1, 141-162. https://doi.org/10.1007/ s10258-002-0009-9

Calton, J., \& Payne, S. (2003). Coping with paradox. Business and Society, 42, 7-42. https://doi.org/10.1177/0007650302250505

Cespa, G., \& Cestone, G. (2007). Corporate social responsibility and managerial entrenchment. Journal of Economics and Management Strategy, 16, 741-771. https://doi.org/10.1111/j.1530-9134.2007.00156.x

Coles, J.L., Daniel, N.D., \& Naveen, L. (2008). Boards: does one size fit all? Journal of Financial Economics, 87, 329-356. https://doi.org/10.1016/j.jfineco.2006.08.008

Davis, J.H., Schoorman, F.D., \& Donaldson, L. (1997). Toward a stewardship theory of management. Academy of Management Review, 22(1), 20-47. https://doi. org/10.2307/259223

Duru, A., Iyengar, R.J., \& Zampelli, E.M. (2016). The dynamic relationship between CEO duality and firm performance: The moderating role of board independence. Journal of Business Research, 69, 4269-4277. https://doi.org/10.1016/j .jbusres.2016.04.001

Ehsan, S., \& Kaleem, A. (2012). An empirical investigation of the relationship between corporate social responsibility and financial performance: Evidence from Manufacturing sector of Pakistan. Journal of Basic and Applied Scientific Research, 2(3), 2909-2922.

Finkelstein, S., \& D’Aveni, R.A. (1994). CEO duality as a double-edged sword: How board of directors balanc entrenchment avoidance and unity of command. Academy of Management Journal, 37(5), 1079-1108. https://doi.org/10.5465/256667

Fisman, R., Heal, G., \& Nair, V. (2006). A model of corporate philanthropy. Working paper, Wharton School, University of Pennsylvania.

Freeman, R. (1984). Strategic management: A stakeholder perspective. Prentice Hall.

Garas, S., \& ElMassah, S. (2018). Corporate governance and corporate social responsibility disclosures: The case of GCC countries. Critical Perspectives on International Business, 14(1), 2-26. https://doi.org/10.1108/cpoib-10-2016-0042

Hair, J.F., Black, W.C., Babin, B.J., \& Anderson, R.E. (2010). Multivariate data analysis (7th ed.). Prentice Hall.

Harjoto, M.A., \& Jo, H. (2011). Corporate governance and CSR nexus. Journal of Business Ethics, 100, 45-67. https://doi.org/10.1007/s10551-011-0772-6

Hassan, M.K., \& Habouni, S.S. (2013). Corporate governance, economic turbulence and financial performance of UAE listed firms. Studies in Economics and Finance, 30(2), 118-138. https://doi.org/10.1108/10867371311325435

Hermalin, B.E., \& Weisbach, M.S. (2003). Boards of directors as an endogenously determined institution: A survey of the economic literature. Economic Policy Review, 9, 7-26. 
Jamali, D., Safieddine, A.M., \& Rabbath, M. (2008). Corporate governance corporate social responsibility synergies and interrelationships. Corporate Governance, 16(5), 443-459. https://doi.org/10.1111/j.1467-8683.2008.00702.x

Jensen, M.C., \& Meckling, W.H. (1976). Theory of the firm: Managerial behavior, agency costs and ownership structure. Journal of Financial Economics, 3(4), 305-360. https://doi.org/10.2307/3857812

Jensen, M.C. (2002). Value maximization, stakeholder theory, and the corporate objective function. Business Ethics Quarterly, 12(2), 235-256. https://doi. org/10.2307/3857812

Karim, S., Manab, N.A., \& Ismail, R.B. (2019a). Legitimising the role of corporate boards and corporate social responsibility on the performance of Malaysian listed companies. Indian Journal of Corporate Governance, 12(2), 125-141.

Karim, S., Manab, N.A., \& Ismail, R.B. (2019b). The dynamic impact of board composition on CSR practices and their mutual effect on organizational returns. Journal of Asia Business Studies. https://doi.org/10.1108/JABS-07-2019-0214.

Kotchen, M., \& Moon, J. (2012). Corporate social responsibility for irresponsibility. The B.E Journal of Economic Analysis \& Policy, 12(1), Article 55, https://doi. org/10.1515/1935-1682.3308.

La Porta, R., Lopez-de-Silanes, F., Shleifer, A., \& Vishny, R. (2000). Investor protection and corporate governance. Journal of Financial Economics, 58, 3-27. https://doi. org/10.1016/S0304-405X(00)00065-9

Lam, T.Y., \& Lee, S.K. (2012). Family ownership, board committees and firm performance: evidence from Hong Kong. Corporate Governance: The International Journal of Business in Society, 12(3), 353-366. https://doi.org/10.1108/14720701211234609

Lipton, M., \& Lorsch, J. (1992). A modest proposal for improved corporate governance. Business Lawyer, 48, 59-77.

Liu, J., \& Taylor, D. (2008). Legitimacy and corporate governance determinants of executives' remuneration disclosures. Corporate Governance, 8(1), 59-72. https://doi.org/10.1108/14720700810853400

MCCG. (2017). Malaysian Code on Corporate Governance Securities Commission Malaysia, Bursa Malaysia.

Mehdi, M., Sahut, J-M, \& Teulon, F. (2017). Do corporate governance ownership structure impact dividend policy in emerging market during financial crisis? Journal of Applied Accounting Research, 18(3), 274-297. https://doi.org/10.1108/JAAR -07-2014-0079

Meyer, J.W., \& Rowan, B. (1977). Institutionalized organizations: Formal structure as myth and ceremony. American Journal of Sociology, 83(2), 340-363. https://doi. org/10.1086/226550

Mishra, R., \& Kapil, S. (2017). Effect of ownership structure and board structure on firm value: evidence from India. Corporate Governance: The International Journal of Business in Society, 17(4), 700-726. https://doi.org/10.1108/CG-03-2016-0059

Mitra, S., Jaggi, B., \& Al-Hayale, T. (2017). The effect of managerial stock ownership on the relationship between material internal control weaknesses and audit fees. Review of Accounting and Finance, 16(2), 239-259. https://doi.org/10.1108/ RAF-05-2016-0072 
Nas, T.I., \& Kalaycioglu, O. (2016). The effects of the board composition, board size and CEO duality on export performance: Evidence from Turkey. Management Research Review, 39(11), 1374-1409. https://doi.org/10.1108/MRR-01-2015 $-0014$

Nuanpradit, S. (2019). Real earnings management in Thailand: CEO duality and services early years. Asia-Pacific Journal of Business Administration, 11(1), 88-108. https://doi.org/10.1108/APJBA-08-2018-0133

Ofoeda, I. (2017). Corporate governance and non-bank financial institutions profitability. International Journal of Law and Management, 59(6), 854-875. https://doi. org/10.1108/IJLMA-05-2016-0052

Olson, B., Parayitam, S., Skousen, B. \& Skousen, C. (2018). How to strike a balance between CEO compensation and strategic risk? A longitudinal analysis. Journal of Strategy and Management, 11(3), 387-417. https://doi.org/10.1108/JSMA-08 $-2017-0055$

Panda, B., \& Leepsa, N.M. (2019). Does institutional ownership engagement matter for greater financial performance? Evidence from a developing market. International Journal of Law and Management, 61(2), 359-383. https://doi.org/10.1108/ IJLMA-09-2017-0228

Porter, M., \& Kramer, M. (2006). Strategy and society: The link between competitive advantage and corporate social responsibility. Harvard Business Review, 84(12), 78-92.

Pound, J. (1988). Proxy contests and the efficiency of shareholder oversight. Journal of Financial Economics, 20, 237-265. https://doi.org/10.1016/0304 $-405 X(88) 90046-3$

Scherer, A., Palazzo, G., \& Baumann, D. (2006). Global rules and private actors, toward a new role of the TNC in global governance. Business Ethics Quarterly, 16, 502-532.

Shan, Y.G. (2017). Managerial ownership, board independence and firm performance. Accounting Research Journal, 32(2), 203-220. https://doi.org/10.5840/ beq200616446

Sheikh, N.A., \& Karim, S. (2015). Effects of internal governance indicators on performance of commercial banks in Pakistan. Pakistan Journal of Social Sciences, 35(1), 77-90.

Shleifer, A., \& Vishny, R. (1997). A survey of corporate governance. Journal of Finance, 52, 737-784. https://doi.org/10.1111/j.1540-6261.1997.tb04820.x

Wang, Z.H. (2016). On the impact of outside blockholders' voting power. Corporate Governance, 16(3), 330-346. https://doi.org/10.1108/CG-05-2015-0074

Wilmshurst, T.D., \& Frost, G.R. (2000). Corporate environmental reporting: A test of legitimacy theory. Accounting, Auditing and Accountability Journal, 13(1), 10-26. https://doi.org/10.1108/09513570010316126

$\mathrm{Wu}, \mathrm{J} ., \quad \& \mathrm{Wu}, \mathrm{Z}$. (2014). Integrated risk management and product innovation in China: The moderating role of board of directors. Technovation, 34(8), 466-476. https:// doi.org/10.1016/j.technovation.2013.11.006

Young, W., \& Wu, C-C. (2017). Abnormal investment, changes in institutional ownership, and SEO long-run performance. Managerial Finance, 43(8), 842-864. 